See discussions, stats, and author profiles for this publication at: https://www.researchgate.net/publication/281450882

\title{
Herbage Accumulation and Nutritive Value of Limpograss Breeding Lines Under Stockpiling Management
}

Article in Crop Science · August 2015

DOI: 10.2135/cropsci2014.11.0797

CITATIONS

2

8 authors, including:

Marcelo Osorio Wallau

University of Florida

34 PUBLICATIONS 31 CITATIONS

SEE PROFILE

Joao M. B. Vendramini

University of Florida

172 PUBLICATIONS 1,052 CITATIONS

SEE PROFILE
READS

144

University of Florida

345 PUBLICATIONS 3,589 CITATIONS

SEE PROFILE

Kim Mullenix

Auburn University

24 PUBLICATIONS 47 CITATIONS

SEE PROFILE

Some of the authors of this publication are also working on these related projects:

Estudio de la mejora en la eficiencia bioeconomica mediante la combinación de diferentes genotipos de vacas y ofertas de forraje en pastoreo de Campos View project

Effect of olive oil bioextracts on weaned female angus calves induced to a low-grade chronic inflammation View project 


\title{
Herbage Accumulation and Nutritive Value of Limpograss Breeding Lines Under Stockpiling Management
}

\author{
M. O. Wallau, L. E. Sollenberger,` J. M. B. Vendramini, M. K. Mullenix, \\ K. H. Quesenberry, C. A. M. Gomide, V. Costa e Silva, and N. DiLorenzo
}

\begin{abstract}
Supplements or conserved forage are often used to overcome forage quantity deficits for beef cattle, but stockpiled forage can be more economical. Limpograss [Hemarthria altissima (Poir.) Stapf \& C.E. Hubb.] is the best available species for stockpiling in Florida because it is productive in autumn and maintains greater digestibility than other grasses at advanced stages of maturity. New limpograss hybrid breeding lines have been developed, but they have not been tested under stockpiling. Three limpograss breeding lines (1, 4F, and 10$)$ and the most-used cultivar, Floralta, received 50 or 100 $\mathrm{kg} \mathrm{N} \mathrm{ha-1}$ at initiation of stockpiling and herbage accumulated for 8,12 , or 16 wk. Entry $4 \mathrm{~F}$ had greater herbage accumulation $\left(7.3 \mathrm{Mg} \mathrm{ha}^{-1}\right)$ than Entries 10, 1, and Floralta (6.1, 6.0, and 5.4 $\mathrm{Mg} \mathrm{ha}^{-1}$, respectively). Entry $4 \mathrm{~F}$ also had greater in vitro digestible organic matter (IVDOM) concentration (530-594 $\mathrm{g} \mathrm{kg}^{-1}$ ) than Entries 1 and Floralta, but $4 \mathrm{~F}$ was not different from Entry 10 (519-531 $\mathrm{g} \mathrm{kg}^{-1}$ ) after 12 and 16 wk of accumulation. As stockpiling period increased from 8 to 16 wk, herbage accumulation increased from 5.3 to $7.4 \mathrm{Mg} \mathrm{ha}^{-1}$, dead material proportion increased from 1 to $10 \%$, and herbage crude protein (CP) decreased from 44 to $32 \mathrm{~g} \mathrm{~kg}^{-1}$. Limpograss hybrids $4 \mathrm{~F}$ and 10 are superior to Floralta for stockpiling, stockpiling period should not be longer than $12 \mathrm{wk}$, and protein supplement will be required to achieve satisfactory animal performance on stockpiled limpograss.
\end{abstract}

M.O. Wallau, L.E. Sollenberger, and K.H. Quesenberry, Agronomy Dep., Univ. of Florida, Gainesville, FL 32611-0500; J.M.B. Vendramini, Range Cattle Research and Education Center, Ona, FL 33865; M.K. Mullenix, Dep. of Animal Sciences, 303A Upchurch Hall, Auburn University, AL 36849; C.A.M. Gomide, Embrapa Gado de Leite, Juiz de Fora, MG, Brazil; V. Costa e Silva, São Paulo State Univ., Jaboticabal, São Paulo, Brazil, 14884-900; N. DiLorenzo, North Florida Research and Education Center, Marianna, FL 32446. Received 25 Nov. 2014. Accepted 20 Jan. 2015. `Corresponding author (lesollen@ufl.edu).

Abbreviations: CP, crude protein; DM, dry matter; DOM/CP, digestible organic matter to crude protein ratio; IVDOM, in vitro digestible organic matter.

Ceasonality of forage production is a major challenge facing $\checkmark$ pasture-based livestock production systems throughout the world. The lack of forage for grazing in the season of shortfall requires supplementation as hay, silage, or concentrate, which increases the cost of livestock production. In central and south Florida, forage quantity limitations most often occur during winter, when cool temperatures and short days limit plant growth of most warm-season perennial grasses. However, the cool season is often not long enough to justify use of cool-season grasses as a forage source. Extending the length of the grazing season of warm-season forages can reduce the need for supplementation. This can be achieved by using cold-tolerant species or cultivars that remain productive after temperatures and day length begin to decrease or alternatively by stockpiling forage for use in winter.

Limpograsses have demonstrated ability to produce more forage during the cool season than any other warm-season perennial grass adapted to Florida (Quesenberry et al., 2004). In

Published in Crop Sci. 55:2377-2383 (2015).

doi: 10.2135/cropsci2014.11.0797

(C) Crop Science Society of America | 5585 Guilford Rd., Madison, WI 53711 USA

All rights reserved. No part of this periodical may be reproduced or transmitted in any form or by any means, electronic or mechanical, including photocopying, recording, or any information storage and retrieval system, without permission in writing from the publisher. Permission for printing and for reprinting the material contained herein has been obtained by the publisher. 
addition, stockpiling limpograss is a common practice in the southern part of the state where mild winter temperatures favor growth later into autumn, allowing limpograss pastures to be used until September and then stockpiled (Kretschmer and Snyder, 1979). Along with its superior cool-season production relative to other perennial grasses, another reason for using limpograss for stockpiling is that herbage IVDOM concentration is generally greater than that of other commonly used C4 grasses at advanced stages of maturity (Quesenberry et al., 2004). A constraint associated with limpograss use is that CP concentration may be below the requirements of most animal classes and protein supplementation may be required (Holderbaum et al., 1991; Lima et al., 1999; Newman et al., 2002).

Recent breeding efforts have resulted in the development of several limpograss hybrids that may have potential for use in Florida. Because stockpiling is a widely used management strategy for limpograss, there is need to evaluate these breeding lines under stockpiling management before consideration for cultivar release. The objective of this study was to assess the potential of three limpograss hybrid lines $(1,4 \mathrm{~F}$, and 10) for use as stockpiled forage and compare them with the current industry standard, Floralta limpograss.

\section{MATERIALS AND METHODS}

\section{Site Description}

The experiment was conducted from August to November 2012 and 2013 in plots that had been established in 2009 at the University of Florida Beef Research Unit, Gainesville, FL $\left(29.72^{\circ} \mathrm{N}, 82.35^{\circ}\right.$ W). The soil was a Smyrna fine sand (sandy, siliceous, hyperthermic, Aeric Alaquods). Soil pH was 6.2, and Mehlich-1 extractable $\mathrm{P}, \mathrm{K}$, and $\mathrm{Mg}$ were 13, 175, and $101 \mathrm{mg} \mathrm{kg}^{-1}$, respectively.

\section{Treatments and Experimental Design}

Treatments (24) included the factorial combinations of four grasses, three stockpiling periods, and two $\mathrm{N}$ fertilizer levels arranged in three replicates of a randomized complete block design. Plots were 1.5 by $1.5 \mathrm{~m}$ with $1-\mathrm{m}$ alleys between them. Limpograss hybrids 1, 10, and 4F were compared with the cultivar Floralta (control). Subsequently, the grasses will be referred to as entries. Nitrogen fertilization levels were 50 and $100 \mathrm{~kg} \mathrm{ha}^{-1}$ and stockpiling periods were 8, 12, and $16 \mathrm{wk}$. The recommended $\mathrm{N}$ fertilization level for stockpiling limpograss is approximately $100 \mathrm{~kg} \mathrm{~N} \mathrm{ha}^{-1}$ (Quesenberry et al., 2004). However, because of the increase in $\mathrm{N}$ fertilizer prices in the last decade, the use of $\mathrm{N}$ fertilizer by livestock producers has been limited. The rationale for the $\mathrm{N}$ levels used was to compare the recommended level with one more likely to be used currently by producers $\left(50 \mathrm{~kg} \mathrm{ha}^{-1}\right)$. Stockpiling periods were chosen based on previous research that indicated at least 8 to $10 \mathrm{wk}$ should be allowed in order for the pastures to accumulate sufficient biomass for autumn-winter use (Quesenberry and Ocumpaugh, 1980). According to the same authors, the best date to start stockpiling limpograss in north-central Florida is early August. Starting at this time provides relatively similar environmental conditions as would occur in south Florida when initiation of stockpiling is approximately mid-September.

Before initiation of the experiment each year, the grasses were grazed approximately every $4 \mathrm{wk}$ throughout the spring and summer of 2012 and 2013 to a 20-cm stubble height. Grasses were clipped to a 20-cm stubble on 1 Aug. 2012 and 8 Aug. 2013, and the forage was removed from the plots. Nitrogen fertilizer was applied according to treatment rate on 10 Aug. 2012 and 19 Aug. 2013. Based on soil test, all plots were

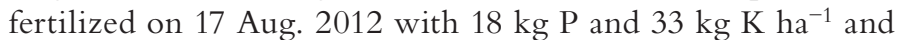
on 8 Aug. 2013 with $10 \mathrm{~kg} \mathrm{P}$ and $37 \mathrm{~kg} \mathrm{~K} \mathrm{ha}^{-1}$. The 8-, 12-, and 16-wk stockpiling periods ended on 26 Sept., 24 Oct., and 21 Nov. 2012, and on 3 Oct., 31 Oct., and 28 Nov. 2013.

\section{Response Variables}

\section{Herbage Dry Matter Accumulated and Herbage Accumulation Rate}

At harvest, one $0.25-\mathrm{m}^{2}$ quadrat was clipped from the center of each plot to a $20-\mathrm{cm}$ stubble height using battery-powered shears. The samples were dried at $60^{\circ} \mathrm{C}$ to constant weight and weighed to determine herbage dry matter (DM) accumulation. Herbage DM accumulation rate during the stockpiling period was calculated as herbage DM accumulation divided by length of the stockpiling period.

\section{Morphological Characteristics}

Average nonextended sward height (referred to as canopy height) was measured with a ruler at five sites per plot at time of harvest. At later stages of maturity, the limpograss canopy had lodged, thus both nonextended and extended canopy heights (the latter referred to as extended stem length) were measured. A lodging index was calculated as the ratio between extended stem length and nonextended canopy height. Bulk density was calculated by dividing herbage accumulation by average nonextended canopy height minus cutting stubble height. To determine plant-part proportion at each harvest date, four hand-plucked samples per plot were taken to a $20-\mathrm{cm}$ stubble height and composited. The composite sample was separated into leaf blade, sheath plus stem (referred to as stem), and dead material fractions. All samples were dried at $60^{\circ} \mathrm{C}$ to constant weight and weighed.

\section{Nutritive Value}

Total herbage CP and IVDOM concentrations were determined using the sample collected to measure herbage accumulation, while plant-part nutritive value was determined using separated hand-plucked samples that were clipped to the same stubble height. All samples were ground to pass a 1-mm stainless steel screen in a Wiley mill (Model 4 Thomas-Wiley Laboratory Mill, Thomas Scientific) before analysis. Analysis for IVDOM was performed using a modification of the two-stage technique (Moore and Mott, 1974). For N analysis, samples were digested using a modification of the aluminum block digestion procedure of Gallaher et al. (1975). Nitrogen in the digestate was determined by semiautomated colorimetry (Hambleton, 1977), and $\mathrm{CP}$ concentration was calculated by multiplying total $\mathrm{N}$ by 6.25. The digestible organic matter to $\mathrm{CP}$ ratio (DOM/CP) of the herbage accumulation samples was calculated by dividing herbage IVDOM by herbage CP. 
Table 1. Canopy morphological characteristics and plant-part proportion of four stockpiled limpograsses. Data are means across two $\mathrm{N}$ fertilization levels, three stockpiling periods, three replicates, and $2 \mathrm{yr}(n=32)$.

\begin{tabular}{|c|c|c|c|c|c|c|c|}
\hline Entry & $\begin{array}{c}\text { Canopy } \\
\text { height }\end{array}$ & $\begin{array}{l}\text { Extended } \\
\text { stem length }\end{array}$ & $\begin{array}{l}\text { Lodging } \\
\text { index }^{\dagger}\end{array}$ & Bulk density & Leaf & Stem & Dead \\
\hline & \multicolumn{2}{|c|}{$\longrightarrow \mathrm{cm}$} & & $\mathrm{kg} \mathrm{ha}^{-1} \mathrm{~cm}^{-1}$ & 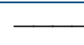 & $-\%-$ & - \\
\hline 1 & $68 b^{\ddagger}$ & $82 b$ & $1.20 b$ & $146 a$ & $23 a$ & $68 \mathrm{c}$ & $6.3 a b$ \\
\hline $4 \mathrm{~F}$ & $81 a$ & $105 a$ & $1.31 \mathrm{a}$ & $141 a b$ & $19 b$ & $75 a$ & $5.6 b$ \\
\hline 10 & $81 a$ & $101 \mathrm{a}$ & $1.26 \mathrm{ab}$ & $122 b$ & $23 a$ & $71 b$ & $6.5 a b$ \\
\hline Floralta & $77 a$ & $100 a$ & $1.32 \mathrm{a}$ & $115 b$ & $19 b$ & $72 a b$ & $7.7 \mathrm{a}$ \\
\hline SE & 2 & 3 & 0.04 & 10.8 & 1.3 & 1.3 & 0.8 \\
\hline
\end{tabular}

${ }^{\dagger}$ Ratio of extended stem length to nonextended canopy height.

${ }^{\ddagger}$ Means within a column not followed by the same letter are different $(P<0.05)$.

\section{Statistical Analysis}

Data were analyzed using PROC GLIMMIX of SAS version 9.4 (SAS Institute, 2013) with $\mathrm{N}$ fertilization level, stockpiling period, and entry as fixed effects. Block and year were considered random effects. Only those main effects and interactions that were significant $(P<0.05)$ are discussed in the text. All reported means are least squares means. Mean separation was accomplished for grass entries using Fisher's F-protected least significant difference test, for $\mathrm{N}$ level means using the F-test, and for length of stockpiling period using polynomial contrasts (linear and quadratic). Differences were declared when $P<$ 0.05 . To satisfy the assumptions of analysis of variance, herbage accumulation and herbage accumulation rate data were transformed using the natural logarithm transformation, but the data reported are nontransformed means.

\section{RESULTS AND DISCUSSION Herbage Accumulation and Accumulation Rate}

Herbage accumulation was affected by entry and stockpiling period $(P<0.001)$. Entry $4 \mathrm{~F}$ had the greatest herbage accumulation (7.3 $\mathrm{Mg} \mathrm{ha}^{-1}$ ), followed by 10 and 1 (6.1 and 6.0 $\mathrm{Mg} \mathrm{ha}^{-1}$, respectively). Floralta had the least herbage accumulation (5.4 $\left.\mathrm{Mg} \mathrm{ha}^{-1}\right)$, however, it was not different from Entry 1. Nitrogen fertilization level had no effect on herbage accumulation $(P=0.851)$, most likely because of the long regrowth intervals used in the study and the previously observed ability of limpograss to achieve excellent herbage accumulation with limited $\mathrm{N}$ availability (Quesenberry et al., 2004). Kretschmer et al. (1996) tested different levels and combinations of initial and late $\mathrm{N}$ fertilization of limpograss, but similar to the results in this study, they did not find differences in herbage accumulation.

There was a linear $(P<0.001)$ effect of length of stockpiling period on herbage accumulation, and it increased from 5.3 to $7.4 \mathrm{Mg} \mathrm{ha}^{-1}$ from 8 to $16 \mathrm{wk}$. Weather conditions may have contributed to the response observed. In both years, there were only a few days in October and November with temperatures below $10^{\circ} \mathrm{C}$ that would be expected to hinder limpograss growth.

There were entry and stockpiling period effects $(P<0.001)$ on herbage DM accumulation rate, but $\mathrm{N}$ fertilization had no effect $(P=0.846)$. Entry $4 \mathrm{~F}$ had the greatest accumulation rate $\left(90 \mathrm{~kg} D M \mathrm{ha}^{-1} \mathrm{~d}^{-1}\right)$, followed by Entries 10 and 1 (both $76 \mathrm{~kg} \mathrm{DM} \mathrm{ha} \mathrm{da}^{-1}$ ). The least productive entry was Floralta $\left(67 \mathrm{~kg} \mathrm{DM} \mathrm{ha}^{-1} \mathrm{~d}^{-1}\right)$, but it was not different from Entry 1 . There was a linear $(P<$ $0.001)$ decrease in accumulation rate from 93 to $67 \mathrm{~kg}$ DM $\mathrm{ha}^{-1} \mathrm{~d}^{-1}$ as length of stockpiling period increased from 8 to $16 \mathrm{wk}$. A companion study at the same location found 2-yr average herbage DM accumulation rates ranging from 80 to $95 \mathrm{~kg} \mathrm{ha}^{-1} \mathrm{~d}^{-1}$ during May to October (Wallau, 2013), thus herbage accumulation rate in the current study was only slightly less than that observed for these limpograss entries during the warm season. Two-year average herbage accumulation rates were $\sim 70 \mathrm{~kg} \mathrm{DM} \mathrm{ha}^{-1} \mathrm{~d}^{-1}$ through October for limpograss cultivar Bigalta following initiation of stockpiling in late July or early August, but rates decreased thereafter (Quesenberry and Ocumpaugh, 1980). Despite the observed linear decrease in accumulation rate with increasing length of stockpiling period in the current experiment, the herbage accumulation rate was positive from 8 to $16 \mathrm{wk}$, illustrating the ability of the new hybrid limpograsses to be productive even during the shorter and cooler days of October and November.

\section{Canopy Height, Stem Length, and Bulk Density}

Canopy height was affected by entry $(P<0.001)$, while extended stem length was affected by both entry and stockpiling period $(P<0.001)$. Entry 1 had the shortest canopy height and extended stem length $(68$ and $82 \mathrm{~cm}$, respectively; Table 1). Among Entries 4F, 10, and Floralta, canopy height (range of 77-81 cm) and extended stem length (range of 100-105 cm) were not different. Length of stockpiling period had linear and quadratic effects $(P<0.001$ and $P=0.004$, respectively) on extended stem length, which increased from 8 to 12 wk (83 and 102 $\mathrm{cm})$ but changed little from 12 to $16 \mathrm{wk}(102-106 \mathrm{~cm}$; Table 2). Lodging index was affected by entry $(P=0.013)$ and stockpiling period $(P<0.001)$. Lodging index was greater for Floralta (1.32) and 4F (1.31) than for Entry 1 (1.20), while Entry 10 was intermediate and not different 
Table 2. Canopy morphological characteristics and plant-part proportion of limpograss at three lengths of stockpiling period. Data are means across two $\mathrm{N}$ fertilization levels, four limpograss entries, three replicates, and $2 \mathrm{yr}(n=48)$.

\begin{tabular}{|c|c|c|c|c|c|c|c|}
\hline $\begin{array}{l}\text { Stockpiling } \\
\text { period }\end{array}$ & $\begin{array}{l}\text { Canopy } \\
\text { height }\end{array}$ & $\begin{array}{l}\text { Extended } \\
\text { stem length }\end{array}$ & $\begin{array}{l}\text { Lodging } \\
\text { index }\end{array}$ & Bulk density & Leaf & Stem & Dead \\
\hline wk & 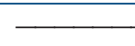 & 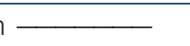 & & $\mathrm{kg} \mathrm{ha}^{-1} \mathrm{~cm}^{-1}$ & 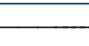 & - \% & 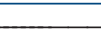 \\
\hline 8 & 77 & 83 & 1.09 & 112 & 10.7 & 74 & 0.8 \\
\hline 12 & 79 & 102 & 1.30 & 121 & 15.6 & 69 & 8.5 \\
\hline 16 & 75 & 106 & 1.43 & 150 & 11.7 & 70 & 10.0 \\
\hline Polynomial contrast ${ }^{\ddagger}$ & NS§ & $L^{* *}, Q^{* \star}$ & $L^{* \star}$ & $L^{* *}$ & NS & $L^{* \star}, Q^{\star *}$ & $L^{\star \star}, Q^{\star \star}$ \\
\hline SE & 2 & 2.6 & 0.03 & 10.8 & 1.1 & 0.9 & 0.7 \\
\hline
\end{tabular}

** Significant at the 0.01 probability level.

${ }^{\dagger}$ Ratio of extended stem length to nonextended canopy height.

‡Polynomial contrast for stockpiling period effect within a response variable; L, linear; Q, quadratic.

$\S \mathrm{NS}$, not significant, $P>0.05$.

Table 3. Limpograss herbage in vitro digestible organic matter (IVDOM) concentration as affected by entry $\times$ stockpiling period interaction. Data are means across two $\mathrm{N}$ fertilization levels, three replicates, and $2 \mathrm{yr}(n=12)$.

\begin{tabular}{|c|c|c|c|c|}
\hline \multirow[b]{2}{*}{ Entry } & \multicolumn{3}{|c|}{ Stockpiling period } & \multirow{2}{*}{$\begin{array}{c}\text { Polynomial } \\
\text { contrast }^{\dagger}\end{array}$} \\
\hline & wk 8 & wk 12 & wk 16 & \\
\hline & $\longrightarrow$ & $\mathrm{g} \mathrm{kg}^{-1}$ & - & \\
\hline 1 & $523 b^{\ddagger}$ & $490 b$ & $493 c$ & NS§ \\
\hline $4 \mathrm{~F}$ & $594 a$ & $530 a$ & $554 a$ & $L^{*}, Q^{\star *}$ \\
\hline 10 & $520 b$ & $519 a b$ & $531 a b$ & NS \\
\hline Floralta & $528 b$ & $465 b$ & $512 b c$ & $Q^{* *}$ \\
\hline SE & 16 & & & \\
\hline
\end{tabular}

* Significant at the 0.05 probability level.

** Significant at the 0.01 probability level.

† Polynomial contrast for stockpiling period effect on herbage IVDOM within an entry; L, linear; $Q$, quadratic.

${ }^{\ddagger}$ Means within a column not followed by the same letter are different $(P<0.05)$.

$\S$ NS, not significant, $P>0.05$.

than the others (1.26; Table 1). Lodging index increased linearly from 1.09 to 1.43 with increasing length of the stockpiling period $(P<0.001$; Table 2$)$.

Entry 1 is a lower growing type and less likely to lodge, while still producing significant amounts of biomass. This may be an advantage for stockpiling management, because canopy characteristics can affect both herbage accumulation and forage intake (Santos et al., 2009). A high lodging index can result in reduced harvest efficiency and wasted forage. Lodging index of 'Basilisk' signalgrass (Brachiaria decumbens Stapf) was positively related to an increase in total herbage mass, stem mass, and dead material mass, and it was negatively related with leaf blade mass (Santos et al., 2009).

Bulk density was affected by entry and stockpiling period effects $(P=0.015$ and $P<0.001$; Table 3,4$)$. Because of a relatively high DM accumulation and shorter canopy, Entry 1 had greater bulk density than Floralta (146 vs. $115 \mathrm{~kg} \mathrm{~cm}^{-1} \mathrm{ha}^{-1}$, respectively). Entries 10 and 4F were intermediate but not different from the others. As a result of increasing extended stem length, maintenance of canopy height, and increase in herbage (especially stem) accumulation, there was a linear $(P<0.001)$ increase in
Table 4. Limpograss total herbage crude protein (CP) concentration and digestible organic matter (DOM)/CP ratio and leaf and stem $\mathrm{CP}$ and in vitro digestible organic matter (IVDOM) concentrations for three stockpiling periods. Data are means across four entries, two $\mathbf{N}$ fertilization levels, three replicates, and $2 \mathrm{yr}(n=48)$.

\begin{tabular}{|c|c|c|c|c|c|c|}
\hline $\begin{array}{l}\text { Length of } \\
\text { stockpiling } \\
\text { period }\end{array}$ & $\begin{array}{c}\text { Total } \\
\text { herbage } \\
\text { CP }\end{array}$ & $\begin{array}{c}\text { Total } \\
\text { herbage } \\
\text { DOM/CP }\end{array}$ & $\begin{array}{l}\text { Leaf } \\
\text { CP }\end{array}$ & $\begin{array}{c}\text { Stem } \\
\text { CP }\end{array}$ & $\begin{array}{l}\text { Leaf } \\
\text { IVDOM }\end{array}$ & $\begin{array}{l}\text { Stem } \\
\text { IVDOM }\end{array}$ \\
\hline wk & $\mathrm{g} \mathrm{kg}^{-1}$ & Ratio & $\longrightarrow$ & - & $\mathrm{kg}^{-1}$ & - \\
\hline 8 & 44 & 13 & 88 & 22 & 538 & 573 \\
\hline 12 & 34 & 16 & 74 & 20 & 518 & 533 \\
\hline 16 & 32 & 18 & 74 & 16 & 529 & 539 \\
\hline $\begin{array}{l}\text { Polynomial } \\
\text { contrast }^{\dagger}\end{array}$ & $L^{\star *}, Q^{\star *}$ & $L^{* *}$ & $L^{\star \star}, Q^{\star \star}$ & $L^{* *}$ & $N S^{\ddagger}$ & $L^{* \star}, Q^{\star \star}$ \\
\hline SE & 5.7 & 0.7 & 1.7 & 1 & 13.8 & 6.2 \\
\hline
\end{tabular}

** Significant at the 0.01 probability level.

† Polynomial contrast for stockpiling period effect on means within a column; L, linear; $Q$, quadratic.

${ }^{\ddagger} \mathrm{NS}$, not significant, $P>0.05$.

herbage bulk density in response to increasing length of stockpiling period (Table 2). Bulk density increased from 112 to $150 \mathrm{~kg} \mathrm{ha}^{-1} \mathrm{~cm}^{-1}$ as stockpiling period increased from 8 to $16 \mathrm{wk}$. This increase in bulk density may create barriers to ingestion of stockpiled limpograss (Sollenberger and Burns, 2001; Burns and Sollenberger, 2002), particularly because it is also associated with decreased leaf proportion and accessibility (Stobbs, 1973; Newman et al., 2003). These features of a mature sward canopy are to be expected because stockpiling is not a strategy to maximize forage quality but to provide forage quantity when most grasses are not actively growing.

\section{Plant-Part Proportion and Mass}

Leaf percentage was affected by entry $(P<0.001)$ but was not affected by stockpiling period $(P=0.107)$ or $\mathrm{N}$ fertilization $(P=0.194)$. Entries 1 and 10 had a greater leaf proportion (both 23\%; Table 1) compared with $4 \mathrm{~F}$ and Floralta (both 19\%). Stem proportion was affected by stockpiling period and entry effects $(P<0.001)$. Entries 
4F and Floralta had a greater stem proportion than Entry 1, but the latter was not different from Entry 10 (Table 1). There were both linear and quadratic effects of stockpiling period $(P<0.001$ and $P=0.002$, respectively) on stem proportion; it decreased from 8 to 16 wk (74 to 69\%, respectively). The decrease in stem proportion over time was unexpected, but it occurred because dead material proportion increased $(0.8,8.5$, and $10 \%$ for 8,12 , and 16 wk, respectively; linear and quadratic, $P<0.001)$. Floralta had greater proportion of dead material compared with 4F (Table 1), but neither was different from Entries 1 and 10 (Table 1). Floralta was among the entries with least leaf and greatest stem and dead matter percentages. These traits generally have a negative impact on animal performance by reducing intake (Sollenberger and Burns, 2001).

\section{Nutritive Value Digestibility}

Total herbage IVDOM was affected by entry $\times$ stockpiling period interaction $(P=0.038)$. Digestibility was greater for $4 \mathrm{~F}$ than 1 or Floralta for all stockpiling periods, but $4 \mathrm{~F}$ digestibility was greater than that of Entry 10 only at 8 wk (Table 3). The interaction also occurred because IVDOM for Entry 4F and Floralta decreased during stockpiling, but there was no effect of stockpiling period on IVDOM of Entries 1 and 10. There were stockpiling period and entry effects $(P<0.001)$ for stem IVDOM and an entry effect $(P$ $=0.004)$ for leaf IVDOM. Stem IVDOM declined from 573 to $533 \mathrm{~g} \mathrm{~kg}^{-1}$ as stockpiling period increased from 8 to $12 \mathrm{wk}$, but there was no further decline between 12 and 16 wk (linear and quadratic effects; $P<0.001$; Table 4). Leaf IVDOM was not affected by length of stockpiling period. Entry $4 \mathrm{~F}$ had greater stem digestibility $\left(576 \mathrm{~g} \mathrm{~kg}^{-1}\right)$ than all other entries; their IVDOM ranged from 534 to $547 \mathrm{~g}$ $\mathrm{kg}^{-1}$ (Table 5). For leaf, Entry 1 had greater IVDOM (564 $\mathrm{g} \mathrm{kg}^{-1}$ ) than all other entries (500 to $522 \mathrm{~g} \mathrm{~kg}^{-1}$ ).

Previous studies reported similar digestibility of other stockpiled limpograss cultivars to those found for Entries 4F and 10 in this study (Carvalho, 1976; Davis et al., 1987; Quesenberry et al., 2004; Arthington and Brown, 2005). Carvalho (1976) measured IVDOM concentrations of 589, 533 , and $516 \mathrm{~g} \mathrm{~kg}^{-1}$ for 8-, 12-, and 16-wk-old Bigalta limpograss regrowth, respectively. Compared with bahiagrass (Paspalum notatum Flüggé), limpograss IVDOM was 155 to $170 \mathrm{~g} \mathrm{~kg}^{-1}$ greater for all regrowth periods, and bahiagrass IVDOM at 22 wk was $226 \mathrm{~g} \mathrm{~kg}^{-1}$ compared with $452 \mathrm{~g} \mathrm{~kg}^{-1}$ for limpograss (Carvalho, 1976). Quesenberry and Ocumpaugh (1980) reported Bigalta limpograss IVDOM above 620 and $550 \mathrm{~g} \mathrm{~kg}^{-1}$ when stockpiled up to $14 \mathrm{wk}$ following uniform clipping that occurred on 1 August. The great majority of warm-season grass hay samples, other than limpograss, submitted to the Florida Extension Forage Testing Program had total digestible nutrient concentrations
Table 5. Total herbage crude protein (CP) concentration and digestible organic matter (DOM)/CP ratio and leaf and stem $\mathrm{CP}$ and in vitro digestible organic matter (IVDOM) concentrations for four limpograss entries. Data are means across three stockpiling periods, two $\mathrm{N}$ fertilization levels, three replicates, and $2 \mathrm{yr}(n=48)$.

\begin{tabular}{lcccccc}
\hline Entry & $\begin{array}{c}\text { Total } \\
\text { herbage } \\
\text { CP }\end{array}$ & $\begin{array}{c}\text { Total } \\
\text { herbage } \\
\text { DOM/CP }\end{array}$ & $\begin{array}{c}\text { Leaf } \\
\text { CP }\end{array}$ & $\begin{array}{c}\text { Stem } \\
\text { CP }\end{array}$ & $\begin{array}{c}\text { Leaf } \\
\text { IVDOM }\end{array}$ & $\begin{array}{c}\text { Stem } \\
\text { IVDOM }\end{array}$ \\
\hline 1 & $\mathrm{~g} \mathrm{~kg}^{-1}$ & Ratio & & & $\mathrm{g} \mathrm{kg}^{-1}$ & \\
$4 \mathrm{~F}$ & $38 \mathrm{a}^{\dagger}$ & $14 \mathrm{~b}$ & 79 & 19 & $564 \mathrm{a}$ & $534 \mathrm{~b}$ \\
10 & $32 \mathrm{~b}$ & $19 \mathrm{a}$ & 76 & 19 & $522 \mathrm{~b}$ & $574 \mathrm{a}$ \\
Floralta & $39 \mathrm{a}$ & $15 \mathrm{~b}$ & 79 & 20 & $510 \mathrm{~b}$ & $547 \mathrm{~b}$ \\
SE & $37 \mathrm{a}$ & $15 \mathrm{~b}$ & 81 & 19 & $517 \mathrm{~b}$ & $539 \mathrm{~b}$ \\
\hline
\end{tabular}

${ }^{\dagger}$ Means within a column not followed by the same letter are different $(P<0.05)$. ‡NS, not significant, $P>0.05$.

ranging from 480 to $510 \mathrm{~g} \mathrm{~kg}^{-1}$, whereas $68 \%$ of limpograss samples were above $510 \mathrm{~g} \mathrm{~kg}^{-1}$ (Moore, 1992).

An unusual characteristic of limpograss is that stem plus sheath IVDOM may be similar to or greater than leaf IVDOM. This is counter to well-established patterns for other species (Sollenberger et al., 2012), but the response is not unique to this experiment. Holderbaum et al. (1992) evaluated plant part and nutrient distribution in limpograss canopies and found leaf IVDOM was lower than stem (529 vs. $550 \mathrm{~g} \mathrm{~kg}^{-1}$, respectively). Kretschmer et al. (1996) sampled stockpiled limpograss canopies in $25-\mathrm{cm}$ strata above a $10-\mathrm{cm}$ stubble height. The three bottom segments (out of five) consisted primarily of stem, but IVDOM concentrations were above $576 \mathrm{~g} \mathrm{~kg}^{-1}$. Thus, despite low leaf percentage in stockpiled herbage, limpograss IVDOM remains high because its stems are more digestible than would be expected.

\section{Crude Protein}

Total herbage $\mathrm{CP}$ was affected by stockpiling period, $\mathrm{N}$ fertilization, and entry main effects $(P<0.001)$. It decreased from 8 to 16 wk (44 to $32 \mathrm{~g} \mathrm{~kg}^{-1}$; linear and quadratic effects, $P<0.001$; Table 4). The magnitude of the $\mathrm{N}$ fertilization effect was small, with CP increasing only from 34 to $39 \mathrm{~g} \mathrm{~kg}^{-1}$ of DM as $\mathrm{N}$ level increased from 50 to 100 $\mathrm{kg} \mathrm{ha}^{-1}$. Among entries, 4F had the lowest CP $\left(32 \mathrm{~g} \mathrm{~kg}^{-1}\right)$ compared with all others, which ranged from 37 to $39 \mathrm{~g}$ $\mathrm{kg}^{-1}$ (Table 5). This lower CP in 4F was associated with the least proportion of leaf and greatest herbage accumulation.

Stem CP was affected only by stockpiling period $(P<$ $0.001)$ and declined linearly from $22 \mathrm{~g} \mathrm{~kg}^{-1} \mathrm{DM}$ at $8 \mathrm{wk}$ to $16 \mathrm{~g} \mathrm{~kg}^{-1}$ at $16 \mathrm{wk}$ (Table 4). Leaf CP declined from 8 to $12 \mathrm{wk}$ ( 88 to $74 \mathrm{~g} \mathrm{~kg}^{-1}$ ), but it remained constant at 74 $\mathrm{g} \mathrm{kg}^{-1}$ thereafter (linear and quadratic effects; $P<0.001$; Table 4). Leaf CP was only slightly greater at $100 \mathrm{~kg} \mathrm{~N}$ $\mathrm{ha}^{-1}\left(81 \mathrm{~g} \mathrm{~kg}^{-1}\right)$ than at $50 \mathrm{~kg} \mathrm{~N} \mathrm{ha}^{-1}\left(77 \mathrm{~g} \mathrm{~kg}^{-1}\right)$.

Total herbage CP was below requirements of all livestock classes, and this response is typical of previous reports 
for other limpograsses. Nearly $80 \%$ of limpograss hay samples submitted by producers for forage testing in Florida had CP below $70 \mathrm{~g} \mathrm{~kg}^{-1}$ (Moore, 1992). Limpograss hay without $\mathrm{N}$ fertilization and harvested at 10-wk regrowth had CP concentration of $30 \mathrm{~g} \mathrm{~kg}^{-1}$ (Arthington and Brown, 2005), and this was less than bahiagrass, bermudagrass [Cynodon dactylon (L.) Pers.], and stargrass (C. nlemfluensis Vanderyst). Across a wide range of $\mathrm{N}$ fertilization levels (0 to $400 \mathrm{~kg}$ $\mathrm{ha}^{-1}$ ), Davis et al. (1987) reported that CP concentration increased from 90 to almost $150 \mathrm{~g} \mathrm{~kg}^{-1}$ for 8 -wk regrowth of Bigalta limpograss. The limited CP response to $\mathrm{N}$ fertilization in the current study was likely due to long stockpiling periods and high levels of herbage accumulation.

While there is little difference in IVDOM between limpograss leaf and stem and among strata in the canopy, plant-part proportion and canopy stratum are important determinants of limpograss CP (Quesenberry et al., 2004). When stockpiled limpograss canopies were sampled in $25-\mathrm{cm}$ strata to a $10-\mathrm{cm}$ stubble height, CP concentration in the upper segments was at least twice as great as the lower ones (Kretschmer et al., 1996), while IVDOM was nearly constant. In rotationally stocked Floralta pastures, stem plus sheath/leaf ratio was 2.1 in the top half of the canopy and 7.3 in the bottom half (Holderbaum et al., 1992). Stem plus sheath averaged $40 \mathrm{~g} \mathrm{CP} \mathrm{kg}^{-1} \mathrm{DM}$ compared with $100 \mathrm{~g} \mathrm{~kg}^{-1}$ for leaf blade. In the current study, plant-part vertical distribution was not quantified, but leaf $\mathrm{CP}$ was approximately four times greater than stem CP. However, leaf composed only 23\% of total herbage for Entries 1 and 10 and 19\% for 4F and Floralta, so its impact on total herbage CP concentration was limited. Although Entries 10 and 4F were superior in some traits to Floralta, $\mathrm{CP}$ concentration was less $(4 \mathrm{~F})$ or not different (10) than Floralta, and protein deficiency is likely when animals are fed stockpiled forage of all entries evaluated.

\section{Digestible Organic Matter/Crude Protein}

Total herbage DOM/CP ratio was affected by entry and stockpiling period $(P<0.001)$ and $\mathrm{N}$ fertilization $(P=$ 0.006). Entry $4 \mathrm{~F}$ had a greater DOM/CP ratio than all other entries (Table 5) due to overall greater IVDOM and lower CP. There was a linear increase in DOM/CP ratio from 13 to 18 as length of stockpiling period increased from 8 to 16 wk. The DOM/CP ratio was less for the greater than the lesser $\mathrm{N}$ fertilization level (15 vs. 17). High DOM/CP ratio of limpograss was previously attributed to stem IVDOM being approximately the same as leaf, while stem CP was only one-half to one-fourth as great as leaf CP (Holderbaum et al., 1992). These characteristics, along with the high percentage of stem in limpograss herbage accumulation, explain the high DOM/CP observed in the current study.

Moore and Kunkle (1995) suggested that cattle grazing forage with DOM/CP ratio above 7 to 8 are likely to increase forage intake and performance when protein supplements are provided. Moore (1992) reported that $81 \%$ of the limpograss samples sent to the Florida Extension Forage Testing Program had total digestible nutrients/ CP ratios above 8 because of high digestibility and relative low CP. Mature lactating beef cows ( $550 \mathrm{~kg}$ body weight) require $945 \mathrm{~g} \mathrm{CP} \mathrm{d}^{-1}$ to maintain a body condition score of 5 and reproductive function (National Research Council, 1996). Considering a stockpiled limpograss forage with a $\mathrm{CP}$ of $44 \mathrm{~g} \mathrm{~kg}^{-1}$ and intake of $21 \mathrm{~g} \mathrm{~kg}^{-1}$ of body weight (Aguiar, 2013), the forage would provide $500 \mathrm{~g} \mathrm{CP} \mathrm{d}^{-1}$ and the remaining $445 \mathrm{~g}$ would have to be provided in supplement. Although stockpiled limpograss is used primarily for mature cows, growing heifers (250 kg body weight) grazing stockpiled limpograss with similar $\mathrm{CP}$ concentration $\left(44 \mathrm{~g} \mathrm{~kg}^{-1}\right.$ ) would also need to receive $\sim 450 \mathrm{~g} \mathrm{CP} \mathrm{d}^{-1}$ to maintain an average daily gain of $0.8 \mathrm{~kg}$ and reach puberty at $\sim 14$ mo of age (Patterson et al., 1992).

\section{SUMMARY AND CONCLUSIONS}

New hybrid breeding lines $4 \mathrm{~F}$ and 10 were more productive under stockpiling management than industry standard cultivar Floralta. Entry $4 \mathrm{~F}$ had lesser leaf percentage and herbage CP but greater herbage IVDOM, stem percentage, and DOM/CP than Floralta. Increasing $\mathrm{N}$ fertilization from 50 to $100 \mathrm{~kg} \mathrm{ha}^{-1}$ had little effect on the response variables measured, and there was insufficient benefit to justify the cost of additional fertilizer. Forage nutritive value decreased less between 12 and 16 wk than between 8 and $12 \mathrm{wk}$, however, herbage accumulation continued to increase through $16 \mathrm{wk}$. Lodging index increased as length of stockpiling period increased, providing a greater challenge to efficient use of herbage for longer stockpiling periods. The length of stockpiling period will likely need to be considerably less than 16 wk to avoid excessive lodging and buildup of stem in the canopy. The new limpograss hybrids 4F and 10 possess advantages that favor their use for stockpiling over Floralta, but regardless of the breeding line or cultivar used, protein supplement will be required to achieve satisfactory levels of animal performance.

\section{Acknowledgments}

We express our appreciation to Richard Fethiere for assistance with laboratory analyses and Dwight Thomas for field support.

\section{References}

Aguiar, A.D. 2013. Grazing management of warm-season grass species in South Florida. Ph.D. diss. University of Florida, Gainesville.

Arthington, J.D., and W.F. Brown. 2005. Estimation of feeding value of four tropical forage species at two stages of maturity. J. Anim. Sci. 83:1726-1731.

Burns, J.C., and L.E. Sollenberger. 2002. Grazing behavior of ruminants and daily performance from warm-season grasses. Crop Sci. 42:873-881. doi:10.2135/cropsci2002.0873 
Carvalho, J.H. 1976. Plant age and its effect upon forage quality. M.S. thesis, University of Florida, Gainesville.

Davis, C.E., V.D. Jolley, G.D. Mooso, L.R. Robison, and R.D. Horrocks. 1987. Quality of stockpiled Bigalta limpograss forage at varying fertility levels. Agron. J. 79:229-235. doi:10.2134/ agronj1987.00021962007900020012x

Gallaher, R.N., C.O. Weldon, and J.G. Futral. 1975. An aluminum block digester for plant and soil analysis. Soil Sci. Soc. Am. Proc. 39:803-806. doi:10.2136/sssaj1975.03615995003900040052x

Hambleton, L.G. 1977. Semiautomated method for simultaneous determination of phosphorus, calcium and crude protein in animal feeds. J. AOAC Int. 60:845-852.

Holderbaum, J.F., L.E. Sollenberger, J.E. Moore, D.B. Bates, W.E. Kunkle, and A.C. Hammond. 1991. Protein supplementation of steers grazing limpograss pasture. J. Prod. Agric. 4:437-441. doi:10.2134/jpa1991.0437

Holderbaum, J.F., L.E. Sollenberger, K.H. Quesenberry, J.E. Moore, and C.S. Jones, Jr. 1992. Canopy structure and nutritive value of rotationally grazed limpograss pasture during mid-summer to early autumn. Agron. J. 84:11-16. doi:10.2134/agronj1992.0 $0021962008400010003 x$

Kretschmer, A.E., and G.H. Snyder. 1979. Production and quality of limpograss for use in the subtropics. Agron. J. 71:37-43. doi:10.2134/agronj1979.00021962007100010009x

Kretschmer, A.E., G.H. Snyder, and T.C. Wilson. 1996. Effects of fall application dates and rates of $\mathrm{N}$ on $\mathrm{N}$ and IVOMD in Bigalta limpograss segments. Proc. Soil Crop Sci. Soc. Fla. 55:116-120.

Lima, G.F.D.C., L.E. Sollenberger, W.E. Kunkle, J.E. Moore, and A.C. Hammond. 1999. Nitrogen fertilization and supplementation effects on performance of beef heifers grazing limpograss. Crop Sci. 39:1853-1858. doi:10.2135/cropsci1999.3961853x

Moore, J.E. 1992. Matching protein and energy supplements to forage quality. In: B. Harris, and B. Haskins, editors, Proc. 3rd Annual Florida Ruminant Nutrition Symposium. Univ. of Florida, Gainesville. Inst. Food Agric. Sci., Gainesville. p. 31-44.

Moore, J.E., and G.O. Mott. 1974. Recovery of residual organic matter from in vitro digestion of forages. J. Dairy Sci. 57:12581259. doi:10.3168/jds.S0022-0302(74)85048-4

Moore, J.E., and W.E. Kunkle. 1995. Improving forage supplementation programs for beef cattle. In: Proc. 6th Annual Florida Ruminant Nutrition Symposium. Univ. Florida, Gainesville, 12-13 Jan. 1995, . p. 65-74.
National Research Council. 1996. Nutrient requirements of beef cattle. 7th ed. Natl. Acad. Press, Washington, DC.

Newman, Y.C., L.E. Sollenberger, A.M. Fox, and C.G. Chambliss. 2003. Canopy height effects on vaseygrass and bermudagrass spread in limpograss pastures. Agron. J. 95:390-394. doi:10.2134/agronj2003.0390

Newman, Y.C., L.E. Sollenberger, W.E. Kunkle, and C.G. Chambliss. 2002. Canopy height and nitrogen supplementation effects on performance of heifers grazing limpograss. Agron. J. 94:13751380. doi:10.2134/agronj2002.1375

Patterson, D.J., R.C. Perry, G.H. Kiracofe, R.A. Bellows, R.B. Straigmiller, and L.R. Corah. 1992. Management considerations in heifer development and puberty. J. Anim. Sci. 70:4018-4035.

Quesenberry, K.H., and W.R. Ocumpaugh. 1980. Crude protein, IVOMD and yield of stockpiled limpograss. Agron. J. 72:10211024. doi:10.2134/agronj1980.00021962007200060037x

Quesenberry, K.H., L.E. Sollenberger, and Y.C. Newman. 2004. Limpograss. In: L.E. Moser, et al., editors, Warm-season (C4) grass monograph. ASA, CSSA, SSSA, Madison, WI. p. 809-832.

SAS Institute. 2013. SAS version 9.4: User's guide. SAS Inst. Inc., Cary, NC.

Santos, M.E.R., D.M. da Fonseca, V.P.B. Euclides, D. do Nascimento, Jr., A.C. de Queiroz, and J.I. Ribeiro, Jr. 2009. Características estruturais e índice de tombamento de Brachiaria decumbens cv. Basilisk em pastagens diferidas. R. Bras. Zootec. 38:626-634. doi:10.1590/S1516-35982009000400006

Sollenberger, L.E., C.T. Agouridis, E.S. Vanzant, A.J. Franzluebbers, and L.B. Owens. 2012. Prescribed grazing on pasturelands. In: C.J. Nelson, editor, Conservation outcomes from pastureland and hayland practices: Assessment, recommendations, and knowledge gaps. Allen Press, Lawrence, KS. p. 111-204.

Sollenberger, L.E., and J.C. Burns. 2001. Canopy characteristics, ingestive behaviour, and herbage intake in cultivated tropical grasslands. In: J.A. Gomide, et al., editors, Proc. Int. Grassl. Cong., 19th, Piracicaba, Brazil, 10-21 Feb. 2001. Brazilian Soc. of Animal Husbandry, Piracicaba, Brazil. p. 321-327.

Stobbs, T.H. 1973. The effect of plant structure on the intake of tropical pastures. I. Variation in the bite size of grazing cattle. Aust. J. Agric. Res. 24:809-819. doi:10.1071/AR9730809

Wallau, M.O. 2013. Evaluation of limpograss (Hemarthria altissima) breeding lines for use in Florida forage-livestock systems. M.S. thesis, University of Florida, Gainesville. 